DOI

\title{
ПОРІВНЯЛЬНА ХАРАКТЕРИСТИКА ПАТОЛОГІЧНИХ ЗМІН У МІЖХРЕБЦЕВИХ ДИСКАХ ХВОСТОВИХ СЕГМЕНТІВ ЩУРІВ ЗА УМОВ МОДЕЛЮВАННЯ ПОСТІЙНОЇ АСИМЕТРИЧНОЇ КОМПРЕСІЇ-ДИСТЕНЗІЇ ТА ПІСЛЯ КОРЕКЦІї ЗБАГАЧЕНОЮ ТРОМБОЦИТАМИ ПЛАЗМОЮ
}

\author{
○О. Л. Холодкова, О. В. Цюрупа, І. Ю. Бадьїн \\ Одеський національний медичний університет
}

\begin{abstract}
РЕЗЮМЕ. В роботі розглянуто актуальне питання пошуку нового методу корекції патологічних змін міжхребцевих дисків та тканин, що їх оточують, за умов експериментальної постійної асиметричної компресіїдистензії. У якості терапевтичного агенту перевірена ефективність збагаченої тромбоцитами плазми. Доведено, що введення збагаченої тромбоцитами плазми приводить до зменшення проявів дегенеративно-дистрофічного процесу та сприяє відтворенню структури ураженого сегмента хребта.

КЛЮчОВІ СЛОВА: міжхребцеві диски, експериментальна постійна асиметрична компресія-дистензія, корекція, збагачена тромбоцитами плазма.
\end{abstract}

Вступ. Хронічні дегенеративно-дистрофічні ураження хребта стають проблемою цивілізації, так званою «платою за прямоходіння» [1], тому пошук методів відтворення структурної цілісності міжхребцевих дисків (МХД) та тканин, що їх оточують, $є$ актуальним питанням сучасної медичної науки. 3 метою стимулювання регенерації МХД використовують остеогенні протеїни, клітинні та тканинні суміші, генномодифіковані клітини [2-4], результати, що їх отримали автори, позитивні, але потребують подальших досліджень.

Останнє десятиріччя збагачена тромбоцитами плазма (ЗТП) активно застосовується при лікуванні широкого кола патологічних процесів - при загоєнні ран [5], трансплантації щелепи [6], експериментальному фіброзі печінки [7] та ін. [8, 9].

Метою нашого дослідження стало виявлення ефективності застосування ЗТП за умов моделювання постійної асиметричної компресії-дистензії у експериментальних тварин.

Матеріал і методи дослідження. В експерименті було задіяно 3 експериментальні групи статевозрілих самців щурів лінії Вістар загальною численністю 90 тварин: І група - інтактні тварини; II група - щури з модельованим дегенеративнодистрофічним ураженням хребта без корекції; III група - щури з корекцією дегенеративнодистрофічного ураження хребта з використанням ЗТП.

Моделювання дегенеративно-дистрофічного ураження хребта у експериментальних тварин виконувалося шляхом формування постійної асиметричної статичної компресії-дистензії хвостового відділу хребта згідно з законом України «Про захист тварин від жорстокого поводження» № 27, ст. 230, від 2006 р. із змінами, внесеними згідно із Законом N 1759-VI (1759-17) від 15.12.2009, ВВР, 2010, N 9, ст. 76, а також загальними етичними принципами експериментів на тваринах (I Націо- нальний конгрес з біоетики, 20.09.2001 р., м.Київ) та Етичним кодексом вченого України (Національна академія наук України, 2009 р.).

Знеболювання тварин було здійснене шляхом введення інгаляції ефіру. Для місцевої анестезії в основу хвоста вводили розчин лідокаїну концентрацією 2 \% у дозі 0,4 мл. Шерсть у ділянці операційного поля видаляли, шкіру обробляли тричі розчином етанолу концентрацією 70 \% та розчином йоду 1 \%. Спочатку проводили резекцію хвоста на рівні CcXIV-CcXV. Потім підшивали куксу П-подібними швами до м'язів та зв'язок попереково-крижового відділу хребта на рівні LIV-SI.

Тварин виводили з експерименту шляхом евтаназії (інгаляційне передозування ефіром). Оцінка результатів була проведена через 60 та 90 діб.

Отримання збагаченої тромбоцитами плазми було здійснено шляхом їі виділення з цільної крові на апараті SmartPrep (фірма-виробник Harvester Corp, USA), свідоцтво про держреєстрацію № 10179/2011 згідно з Наказом Держлікінспекції МОЗ України від 08 лютого 2011 р. № 69.

Після виведення тварин з експерименту у площині найбільшого вигину хвоста були вирізані блоки тканин з двох сегментів хребта. Після фіксації в розчині нейтрального формаліну в концентрації 10 \%, декальцинації в азотній кислоті концентрацією 7,5 \% та проведення через спирти зростаючої концентрації блоки тканин занурювалися у парафіно-воскову суміш. Мікротомні зрізи хребців та міжхребцевих дисків завтовшки 5 мкм, забарвлені гематоксиліном-еозином та за Ван-Гізон були досліджені з використанням звичайної та поляризаційної мікроскопії та методик морфометрії [10].

Для оцінки морфофункціонального стану хребців та міжхребцевих дисків у кожній групі експериментальних тварин було проведене дослідження кісткового епіфіза, епіфізарного хряща, 
Огляди літератури, оригінальні дослідження, погляд на проблему

фіброзного кільця та драглистого ядра, виміряна висота кісткового епіфіза та епіфізарного хряща.

Результати й обговорення. Через 60 діб компресії в гістологічних препаратах спостерігали помітну асиметрію структур хребців та міжхребцевих дисків, виражені патологічні зміни в них. Результати порівняльного морфометричного дослідження товщини МХД на стороні дистензії та компресії свідчать, що показники товщини фіброзного кільця на боці дистензії, величина вогнищ некрозу фіброзного кільця на стороні компресії, ступінь зміщення драглистого ядра у бік дистензії значно збільшувалися. Товщина фіброзного кільця на боці компресії була меншою, ніж у інтактних тварин, а величина вогнищ некрозу фіброзного кільця на боці дистензії - значно меншою за цей показник на боці компресії. Кількість некротизованих клітин у драглистому ядрі практично не змінювалася.

Максимальні дегенеративно-дистрофічні ознаки фіброзного кільця виявили на боці компресії. Колагенові пластини фіброзного кільця були сплющені та розшаровані. У центральних ділянках сплющення спостерігали виражену дезорганізацію і механічне руйнування колагенових пластин 3 безліччю поліморфних щілин. У цих ділянках виявлено поширені вогнища фібронекрозу колагенових пластин, які доходили до місць прикріплення їх до епіфіза.

У драглистих ядрах також виявлені патологічні зміни: зменшення порожнини, що займає драглисте ядро; на боці компресії з фіброзного кільця в порожнину драглистого ядра вибухають частини внутрішніх колагенових пластин. У самому драглистому ядрі зміни різнорідні. У частині МХД драглисті ядра побудовані з солідних скупчень нотохордальних клітин, в частині - з тяжистих комплексів, місцями відзначена виражена вакуолізація цитоплазми нотохордальних клітин. Деякі клітини некротизовані, ядра їх гіпохромні.

\section{ЛITEPATУРA}

1. Lotz J. C. Animal models of intervertebral disc degeneration: lessons learned / J. C. Lotz // Spine. - 2004. Vol. 29, № 23. - P. 2742-2750.

2. Gruber H. E. Anti-apoptotic effects of IGF-1 and PDGF on human intervertebral disc cells in vitro / H. E. Gruber, H. J. Norton, E. N. Hanley // Spine. - 2000. - Vol. 25. P. 2153-2157.

3. Влияние культивированных аутогенных клеток студенистого ядра на структуру межпозвонковых дисков хвостовых сегментов при моделировании остеохондроза у крыс / В. В. Григоровский, М. В. Хижняк, И. Г. Васильев [и др.] // Український нейрохірургічний журнал. - 2013. - № 2. - С. 28-33.

4. Biologic response of human intervertebral disc cells to gene therapy cocktail / S. H. Moon, K. Nishida,
Висота епіфізів тіл, прилеглих до тканин МХД на стороні компресії, була неоднакова: в окремих сегментах хвостового відділу спостерігали як зменшення висоти кісткового епіфіза, так і збільшення; в деяких спостереженнях асиметрія висоти частин епіфіза була непомітна.

У тварин після корекції ЗТП були достовірно: менша кількість вогнищ хондронекрозу; менший ступінь розволокнення колагенових волокон; зменшена виразність асиметрії тканин між сторонами компресії та дистензії; більша товщина фіброзного кільця на боці компресії порівняно $з$ групою тварин без корекції. Під сумнівом: зменшення кількості некротизованих клітин у драглистому ядрі; зміна висоти епіфізів тіл хребців. Незмінно: асиметрія розташування драглистого ядра міжхребцевого диска.

Отримані дані дають підставу вважати, що ЗТП, яка містить велику кількість факторів росту та стовбурові клітини $[11,12]$, відіграє роль активатора власних клітин-попередників хондрогенезу та остеогенезу, а судинна сітка, що утворюється навколо ураженої ділянки хребта, зменшує ступінь ішемічного ураження, стимулює процеси регенерації, сприяє відтворенню структурнофункціональної здатності хребта.

Висновки. Згідно з отриманими даними, збагачена тромбоцитами плазма позитивно впливає на регенеративні процеси в тканинах міжхребцевих дисків. Завдяки факторам росту вона сприяє відтворенню структури тканин, що оточують МХД, та гальмує процес дегенерації дисків.

Перспективи подальших досліджень. Застосований метод корекції дегенеративнодистрофічного ураження МХД потребує додаткового дослідження з метою з'ясування тривалості позитивного ефекту, виявлення конкретних механізмів впливу компонентів ЗТП на уражені тканини.

L. G. Gilbertson [et al.] // Spine. - 2008. - Vol. 33, № 17. P. 1850-1855.

5. Fréchette J.-P. Platelet-rich Plasmas: Growth Factor Content and Roles in Wound Healing / J.-P. Fréchette, I. Martineau, G. Gagnon// Journal Dental Resistant.-2005.Vol. 84. - P. 434-438.

6. The efficacy of platelet-rich plasma in grafted maxillae. A randomised clinical trial / M. Badr, P. Coulthard, R. Alissa, R. Oliver // European Journal Oral Implantology. 2010. - Vol. 3, № 3. - P. 233-244.

7. Холодкова О. Л. Можливості використання збагаченої тромбоцитами плазми при експериментальній терапії токсичного ураження печінки / О. Л. Холодкова, Д. М. Горчаг // Український морфологічний альманах. 2013. - T. 11, № 3. - С. 63-65. 
Огляди літератури, оригінальні дослідження, погляд на проблему

8. Zhao Y. Research progress of platelet-rich plasma in promoting bone regeneration and repairing / Y. Zhao, W. Zhai // Zhongguo Xiu Fu Chong Jian Wai Ke Za Zhi. 2010. - Vol. 24, № 8. - P. 1004-1008.

9. Platelet-rich plasma injection for chronic Achilles tendinopathy: a randomized controlled trial / R. J. de Vos, A. Weir, H. T. van Schie [et al.] // JAMA. - 2010. - Vol. 303, № 2. - P. 144-149.

10. Микроскопическая техника : руководство / под ред. Д. С. Саркисова и Ю. Л. Петрова. - М. : Медицина, 1996. - 544 с.
11. Platelet content and growth factor release in platelet-rich plasma: a comparison of four different systems / G. C. Leitner, R. Gruber, J. Neumüller [et al.] // Vox Sang. - 2006. - Vol. 91. - P. 135-139.

12. Platelet-derived growth factors enhance proliferation of human stromal stem cells / Lucarelli E., Beccheroni A., Donati D. [et al.] // Biomaterials. - 2003. - Vol. 24. P. 3095-3100.

\section{COMPARATIVE CHARACTERISTICS OF THE PATHOLOGICAL CHANGES IN THE INTERVERTEBRAL DISCS AT THE CONDITION OF CONSTANT ASYMMETRIC COMPRESSION- DISTENSION MODELING AND AFTER THE PLATELET-RICH PLASMA CORRECTION}

○O. L. Kholodkova, O. V. Tsyurupa, I. Yu. Badyin

\section{Odesa National Medical University}

SUMMARY. In the paper the actual problem of the new method of pathological changes in the intervertebral discs and surrounded tissues at the state of experimental constant asymmetric compression-distension was discussed. As the therapeutic agent the effectiveness of platelet-rich plasma was testified. It was proved the platelet-rich plasma injection depresses the degenerative-dystrophic process manifestations and improves the affected segment of the spine regeneration.

KEY WORDS: intervertebral discs; experimental constant asymmetric compression-distension; correction; plateletrich plasma.

Отримано 30.10 .2015 